Article

\title{
Assessment of Green Investments' Impact on Sustainable Development: Linking Gross Domestic Product Per Capita, Greenhouse Gas Emissions and Renewable Energy
}

\author{
Serhiy Lyeonov ${ }^{1}$, Tetyana Pimonenko ${ }^{2}$, Yuriy Bilan $\left.{ }^{3}{ }^{(}\right)$, Dalia Štreimikiené ${ }^{4, *}(\mathbb{D})$ and \\ Grzegorz Mentel ${ }^{5}$ (D) \\ 1 Economic Cybernetics Department, Sumy State University, 40007 Sumy, Ukraine; \\ s.lieonov@uabs.sumdu.edu.ua \\ 2 Marketing Department, Sumy State University, 40007 Sumy, Ukraine; \\ tetyana_pimonenko@econ.sumdu.edu.ua \\ 3 Faculty of Management, University of Social Science, 37-400 Lodz, Poland; yuriy_bilan@yahoo.co.uk \\ 4 Vilnius University, Kaunas Faculty, Mutines 8, LT-44280 Kaunas, Lithuania \\ 5 College of Management, Department of Economics and Finance, University of Information Technology and \\ Management in Rzeszow, 35-225 Rzeszow, Poland; gmentel@wsiz.rzeszow.pl \\ * Correspondence: dalia.streimikiene@lei.lt; Tel.: +370-6140-3424
}

Received: 27 August 2019; Accepted: 11 October 2019; Published: 15 October 2019

\begin{abstract}
The paper analyses the linkages between GDP per capita, greenhouse gas (GHG) emissions, and renewable energy (RE) in the total final energy consumption and green investments (PICE) which are measured as private investments, jobs, and gross value added related to circular economy sectors. The object of the analysis is the EU countries during the 2008-2016 period (crisis and post-crisis period). In the paper, data from the following databases was used: the Eurostat, the World Data Bank, and the European Environmental Agency. For addressing the linkages between the aforementioned indicators, the following methods were applied: panel unit root test, Pedroni panel cointegration tests, and the fully modified ordinary least squares (FMOLS) and dynamic ordinary least squares (DOLS) panel cointegration techniques. The findings show that FMOLS and DOLS demonstrate the same results as GHG, PICE, RE influence on GDP of the EU countries. The findings prove there is linking between gross domestic product per capita, greenhouse gas emissions, renewable energy in the total final energy consumption and green investments. The findings also show that green investment (PICE) could provoke the growth of GDP per capita by $6.4 \%$, the decline of GHG by $3.08 \%$, and the increase of renewable energy in the total final energy consumption by $5.6 \%$.
\end{abstract}

Keywords: sustainable development; renewable energy; greenhouse gas emissions; green investments

\section{Introduction}

The current tendency of greening the economic development contributes to analysing the most significant drivers that boost this process. All EU countries signed the agreement on achieving Sustainable Development Goals 2030 (SDGs 2030). According to this agreement, the EU countries, on a voluntary basis, try to reduce their negative impact on the environment and harmonise their economic, social, and environmental development. The results of many studies [1-5] indicate that one of the main drivers which provide the financial base for sustainable development is green investment. Several studies $[6,7]$ have found that the biggest share of green investments was spent on spreading and implementing renewable energy which could reduce greenhouse gas emissions (GHG emissions) $[8,9]$. 
Noteworthy here, the experts have created the Sustainable development goal index to demonstrate countries' success on the way to achieving SDGs 2030. Thus, according to the official report [10], in 2018, the first five places were occupied by Sweden, Denmark, Finland, Germany. All these countries belong to the group of high-income countries in which 2016 Gross National Income (GNI) per capita was $\$ 12,235$ or higher. For these countries, allocation of additional capital for achieving SDGs is not a huge issue.

At the same time, such countries as Slovak Republic, Hungary, Portugal, Poland, Bulgaria, Serbia, Romania, Greece occupied the ranks from 25 to 48. Among these countries, three are high-income countries (Slovak Republic, Hungary and Greece) and upper-middle-income countries with 2016 GNI per capita being between $\$ 3,956$ and $\$ 12,235$ (Bulgaria, Serbia, Romania), only Moldova belongs to low middle-income countries in this group.

In this case, for upper and low middle-income countries allocation of additional financial resources is a big issue due to their unstable economic situation. As green investments can help in achieving important sustainable development goals: GDP per capita growth, increase of renewable energy utilisation and GHG emission reduction, the main input of this paper is to test this hypothesis and to assess the impact of green investments on GDP per capita, the share of renewables in the final energy consumption and GHG emissions in the EU member states and to develop policy recommendations stemming from the results of this empirical study.

As indicated above, increasing the share of renewable energy in the total energy consumption requires additional financial resources. In this case, it would be appropriate to analyse the statistical significance between GDP per capita, GHG emissions, renewable energy consumption and the volume of green investments. The authors of this paper have checked the following hypothesis:

H1: There is a linking between green investment, GDP per capita, GHG emissions and the share of renewable energy in the total energy consumption.

In the next section of this paper, data and methods used are presented. Note that our previous investigation has been focused on a more general analysis of green investment development. In this case, the object of our analysis is the EU countries during the 2008-2016 period while our purpose has been to explain that green investment is one of the ways to attract financial resources.

The reminder of the paper is structured in the following way: Section 2 provides a literature review on the subject and formulation of the hypothesis; Section 3 delivers data and methods applied in the study; Section 4 presents discussions of the results and Section 5 concludes.

\section{Literature Review}

The main dimensions of sustainable development then GDP per capita is growing selected for this study are as follows: use of renewable energy sources and GHG emission reduction. These are also the main EU energy policy targets including energy efficiency increase. In addition, increase of utilisation of renewable energy sources also provides for energy efficiency improvements [2].

According to the dataset, the EU as the whole tries to decrease the GHG emissions compare to the 1990 year (Figure 1).

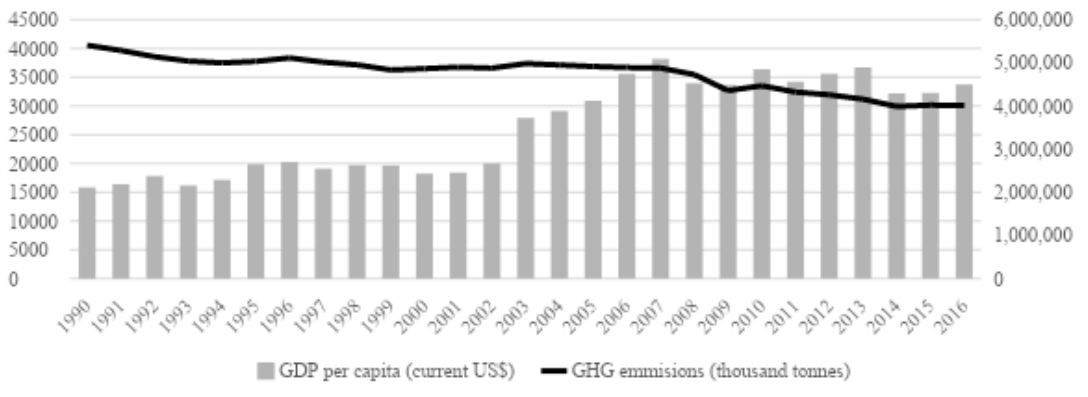

Figure 1. GDP per capita and greenhouse gas emissions (GHG) emissions for EU countries (1990-2016) [11,12]. 
In this case, the snowballing effect on decreasing GHG emissions could be achieved through increasing the share of renewable energy in total energy consumption (Figure 2).

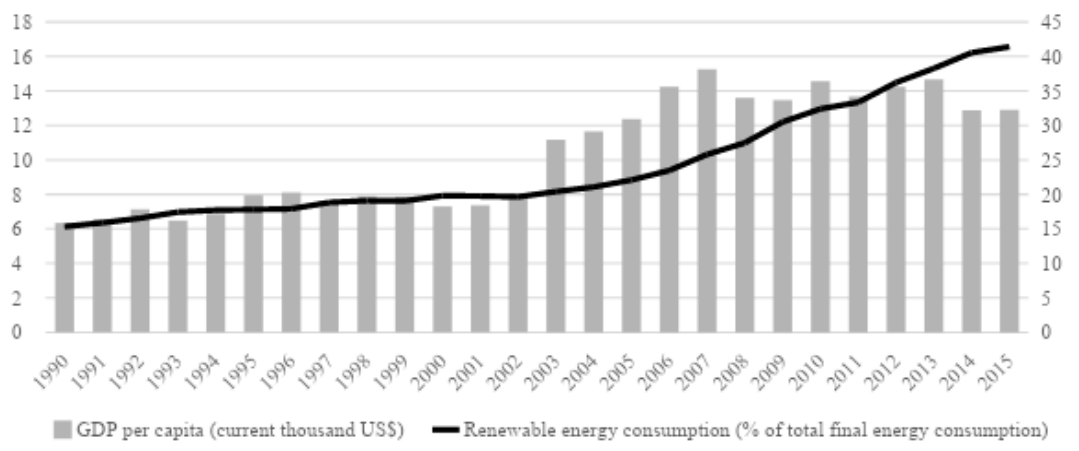

Figure 2. GDP per capita and renewable energy consumption for EU countries (1990-2015) [11,12].

The findings in Figures 1 and 2 showed that increasing the share of renewable energy in total energy consumption leads to decreasing GHG emissions.

The huge range of investigation deals with the analysis of preconditions to develop green investment market as a financial driver of sustainable development. However, according to the results of the previous investigations [13-23] the main factor which restricts the developing of green investment market is misunderstanding the meaning and goals of green investment among scientists, experts and investors. Thus, Martinez-Oviedo and authors in the papers [24-31] highlighted that green investment is a capital to low carbon and climate resilient initiatives, clean technologies, renewable energy, or natural capital that can be considered environmentally beneficial. The one group of scientists proved that the main goal of green investment is declining of $\mathrm{CO}_{2}$ emission [32-45]. The third group of scientists defined green investment as investment into renewable energy [46-63]. In this case, it is necessary to investigate and develop the universal approach to define and classify green investment which will be based on the classification of green assets.

It should be underlined, that a lot of the scientists investigate the relationship between economic development and efficiency of SDGs 2030 achieving through the analysis of linking between: Environmental Performance Index and countries GDP [31,64-67], Environmental Performance Index and Institutions Quality [68-72]; economic, social and ecological indicators of the countries development [73-84], socioeconomic development and economic growth [85], economic growth, environmental pollution and social development which measured by the level of morbidity [86-89].

The author Greco in the paper [89] analysed the sustainable economic development from the point of view of behavioural economics theory. Greco [89] highlighted that the economic growth related to the solving of social conflict and improving the quality of life and work conditions.

The scientist [90-95] proved the hypotheses on linking between ecological, social and economic indicators which influence on country's GDP. The scientists Zajączkowska M. [95], Kisiała W. [96] and Malkina, M. [97] proved the relationship between social indicators, ecological indicators which include efficiency of renewable energy, macroeconomic stability in low-middle income countries [79-99]. Besides, the range of scientists [99] paid attention to analyse the linking between political parameters on economic growth (eliminating of the ecological factors).

Some group of authors in the paper [100-112] tried to prove the relationship between renewable energy, economic growth and volume of foreign direct investment in energy efficient projects and country's brand. In this case, the foreign direct investment analysed as the green investment by the authors. Noted, that using such types of green investment limited the complexity of impact analysis of green investment in the efficiency of sustainable economic development.

The findings allowed making conclusions that most investigation analysed the correlation between $\mathrm{CO}_{2}$ emissions, renewable energy and investment in renewable energy. Under this investigation, the authors analysed instead of $\mathrm{CO}_{2}$ emissions - GHG emission as it was indicated the goal of SDGs 
2030. Therefore, green investment was defined as the private investments, jobs, and gross value added related to circular economy sectors which are an integrated indicator which involves the social, ecological and economic impact of the investment.

\section{Data and Methods}

For checking $\mathrm{H} 1$ hypothesis and further analysis of the main drivers of sustainable development, the authors used the modified model of economic growth as follows:

$$
\mathrm{GDP}=\mathrm{F}(\mathrm{PICE}, \mathrm{GHG}, \mathrm{RE})
$$

where GDP - GDP per capita, PICE - private investments, jobs and gross value added related to circular economy sectors; GHG - GHG emission; RE - share of renewable energy in the total energy consumption.

Modified function (2) can be demonstrated as panel cointegration equation:

$$
\ln \mathrm{GDP}_{i \mathrm{t}}=\phi+\alpha \ln \mathrm{PICE}_{i \mathrm{t}}+\beta \ln \mathrm{GHG}_{i \mathrm{t}}+\gamma \ln \mathrm{RE}_{i \mathrm{t}}+\mu_{i \mathrm{t}}
$$

where $\alpha, \beta, \gamma$-regression's parameters which are evaluated and explain the elastic of output relate on PICE, GHG, RE; $\mu$ is the error term; $i=1, \ldots, N ; t=1, \ldots, T$.

For checking above-mentioned hypotheses, the authors used the databases as follows: World Data Bank, Eurostat, European Environmental Agency. For the analysis, the EU countries during the 2008-2016 period were chosen (Table 1).

\begin{tabular}{|c|c|c|}
\hline Variables & Meaning & Sources \\
\hline GDP per capita (GDP) & $\begin{array}{l}\text { GDP per capita is gross domestic product divided } \\
\text { by midyear population. GDP is the sum of gross } \\
\text { value added by all resident producers in the } \\
\text { economy plus any product taxes and minus any } \\
\text { subsidies not included in the value of the } \\
\text { products. It is calculated without making } \\
\text { deductions for depreciation of fabricated assets or } \\
\text { for depletion and degradation of natural }\end{array}$ & World Data Bank [11] \\
\hline Greenhouse gas emissions (GHG) & $\begin{array}{l}\text { Total greenhouse gas emissions in kt of } \mathrm{CO}_{2} \\
\text { equivalent are composed of } \mathrm{CO}_{2} \text { totals excluding } \\
\text { short-cycle biomass burning (such as agricultural } \\
\text { waste burning and Savannah burning) but } \\
\text { including other biomass burning (such as forest } \\
\text { fires, post-burn decay, peat fires and decay of } \\
\text { drained peatlands), all anthropogenic } \mathrm{CH}_{4} \\
\text { sources, } \mathrm{N}_{2} \mathrm{O} \text { sources and F-gases (HFCs, PFCs } \\
\text { and } \mathrm{SF}_{6} \text { ). }\end{array}$ & $\begin{array}{c}\text { European Environment Agency } \\
\text { [12] }\end{array}$ \\
\hline Green Investment (PICE) & $\begin{array}{l}\text { Private investments, jobs and gross value added } \\
\text { related to circular economy sectors. The indicator } \\
\text { includes "Gross investment in tangible goods", } \\
\text { "Number of persons employed" and "Value } \\
\text { added at factor costs" }\end{array}$ & Eurostat [113] \\
\hline Renewable energy (RE) & $\begin{array}{c}\text { The share of renewable energy in total energy } \\
\text { consumption }\end{array}$ & $\begin{array}{l}\text { Eurostat and the European } \\
\text { Environment Agency }[12,113]\end{array}$ \\
\hline
\end{tabular}

Table 1. Indicators, meaning and sources for analysis

Sources: compiled by the authors.

Under the research, the following methods were used: panel unit root tests using the Im, Pesaran, and Shin's (IPS); Levin, Lin, and Chu test (LLC); and the Fisher-type tests (Augmented Dickey-Fuller test (ADF) Fisher and Phillips-Perron test (PP) Fisher). In the basis of the abovementioned tests is the checking of the hypothesis, which assumed the existing a unit root in the panel data on the time series and alternative absence in the unit root. 
With the purpose to check the long-term correlation, the authors used Pedroni test. If the cointegration exists, the long-run equilibrium relationship will estimate using the Fully Modified OLS (FMOLS) and Dynamic OLS (DOLS) panel cointegration techniques.

For analysis, the EU countries were chosen for period 2000-2016 years. Such countries were chosen as an example for the countries' potential candidate to EU membership to prove the efficiency of green investment and stimulate the attractiveness of green investment as a part of the direct foreign investment. Such investigation could be a base for the further analysis of options to minimize the gaps between EU policy and the countries' potential candidate to EU membership.

\section{Discussion of Results}

At the first stage, the panel unit root tests for parameters GDP, GHG, PICE, RE were done. The results of the panel unit root tests for GDP, GHG, PICE, RE were presented in Table 2.

Table 2. Panel unit root results for GDP, GHG, green investment (PICE), renewable energy (RE).

\begin{tabular}{ccccccccc}
\hline \multirow{2}{*}{ Variables } & \multicolumn{2}{c}{ LLC } & \multicolumn{2}{c}{ IPS } & \multicolumn{2}{c}{ ADF } & \multicolumn{2}{c}{ PP } \\
& Stat. & Prob. & Stat. & Prob. & Stat. & Prob. & Stat. & Prob. \\
\hline \multirow{2}{*}{ GDP } & -2.86 & 0.002 & 0.59 & 0.72 & 59.64 & 0.16 & 55.32 & 0.28 \\
PICE & -4.13 & 0.00 & -0.16 & 0.44 & 64.16 & 0.12 & 58.66 & 0.24 \\
GHG & -7.76 & 0.00 & -3.09 & 0.001 & 99.08 & 0.0001 & 154.09 & 0 \\
RE & -6.04 & 0.00 & 0.58 & 0.28 & 74.01 & 0.02 & 88.57 & 0.0012 \\
& & & & 1 1st differences & & & & \\
GDP & -24.05 & 0.00 & -9.54 & 0.00 & 184.36 & 0.00 & 260.56 & 0.00 \\
PICE & -17.78 & 0.00 & -7.20 & 0.00 & 159.45 & 0.00 & 215.83 & 0.00 \\
GHG & -20.57 & 0.00 & -9.52 & 0.00 & 191.90 & 0.00 & 261.07 & 0.00 \\
RE & -11.76 & 0.00 & -5.04 & 0.00 & 132.10 & 0.00 & 177.93 & 0.00 \\
\hline
\end{tabular}

Sources: calculated by the authors.

The findings (Table 2) of using Levin Lin and Chu (LLC), Im Pesaran and Shin (IPS), ADF Fisher Chi-square and PP Fisher Chi-square tests confirmed that all variables were non-stationary at levels and after the first difference, all variable had become stationary. The obtained results allowed indicating the character of stationary of GDP, GHG, PICE, RE, for EU countries but also established the basis for panel cointegration analysis as the using of the regressions on non-stationary variables can give misleading parameter estimates in the economic relationship among variables. All findings are statistically significant at the level $-1 \%$ and $5 \%$. The findings allowed realising the test for panel cointegration between GDP, GHG, PICE, RE. The cointegration test was conducted using by the Pedroni panel cointegration tests (Table 3).

Table 3. Pedroni panel cointegration tests.

\begin{tabular}{|c|c|c|c|c|c|}
\hline \multirow{2}{*}{ Dimension } & \multirow{2}{*}{ Test Statistics } & \multirow{2}{*}{ Stat } & \multirow{2}{*}{ Prob } & \multicolumn{2}{|c|}{ Weighted statistic } \\
\hline & & & & Stat & Prob \\
\hline \multirow{4}{*}{ Within-dimension } & panel v-statistic & -1.19 & 0.88 & -1.09 & 0.86 \\
\hline & panel rho-statistic & 2.54 & 0.99 & 2.70 & 0.99 \\
\hline & panel PP-statistic & -2.85 & $(0.002)^{* *}$ & -2.83 & $(0.002)^{* *}$ \\
\hline & panel ADF-statistic & -2.85 & $(0.002)^{* *}$ & -2.70 & $(0.0034)^{* *}$ \\
\hline \multirow{3}{*}{ Between-dimension } & group rho-statistic & 5.02 & 1.00 & & \\
\hline & group PP-statistic & -3.20 & $(0.0007)^{* *}$ & & \\
\hline & group ADF-statistic & -2.32 & $(0.01) *$ & & \\
\hline
\end{tabular}

Note: ${ }^{*}$ and ${ }^{* *}$ represents significance at the $1 \%$ and $5 \%$ levels. 
Thus, the findings in Table 3 showed that six from eleven results of the test exclude null hypothesis (no cointegration of time series). Therefore, the obtained results affirmed the cointegration between GDP, GHG, PICE, RE for the EU countries existed on significance at the $1 \%$ and $5 \%$ levels. It allows making the conclusion, about the long-term relationship among GDP, GHG, PICE, RE which could be checked by using the FMOLS and DOLS panel cointegration techniques. For that purpose, four assumptions were checked:

- $\quad$ assumption 1: Influence of GHG, PICE, RE on GDP;

- $\quad$ assumption 2: Influence of GDP, PICE, RE on GHG;

- $\quad$ assumption 3: Influence of GDP, PICE, GHG on RE;

- $\quad$ assumptions 4: Influence of GDP, GHG, RE on PICE.

The obtained results of using FMOLS and DOLS panel cointegration techniques were presented in Table 4.

Table 4. The findings of the fully modified ordinary least squares (FMOLS) and dynamic ordinary least squares (DMOLS) panel cointegration techniques for four assumptions.

\begin{tabular}{|c|c|c|c|c|c|}
\hline \multicolumn{2}{|c|}{ Variables } & \multicolumn{2}{|l|}{ FMOLS } & \multicolumn{2}{|l|}{ DMOLS } \\
\hline Dependent & Independent & Coefficient & Prob & Coefficient & Prob \\
\hline \multirow{3}{*}{ GDP } & PICE & 6.40 & $(0.00) *$ & 5.80 & $(0.00) *$ \\
\hline & GHG & 0.39 & $(0.00) *$ & 0.41 & $(0.00) *$ \\
\hline & RE & 38.18 & $(0.00)$ * & 37.24 & $(0.00) *$ \\
\hline \multirow{3}{*}{ GHG } & GDP & 9.35 & $(0.00)$ * & 9.33 & $(0.00)$ * \\
\hline & PICE & -3.08 & 0.27 & 4.61 & 0.33 \\
\hline & $\mathrm{RE}$ & -5139.85 & $(0.00)$ * & -5142.43 & $(0.00) *$ \\
\hline \multirow{3}{*}{$\mathrm{RE}$} & GDP & 0.002 & $(0.00)^{*}$ & 0.0021 & $(0.00) *$ \\
\hline & PICE & 5.600 & $(0.00)$ * & 7.0 & $(0.0002)$ * \\
\hline & GHG & 0.01 & $(0.00) *$ & 0.0021 & $(0.003) *$ \\
\hline \multirow{3}{*}{ PICE } & GDP & 0.19 & $(0.0001)$ * & 0.21 & $(0.005) *$ \\
\hline & GHG & 0.004 & $(0.0003)$ * & 0.0053 & $(0.002) *$ \\
\hline & $\mathrm{RE}$ & 99.44 & $(0.01)^{* *}$ & 100.31 & $(0.013)^{* *}$ \\
\hline
\end{tabular}

The findings showed that FMOLS and DOLS demonstrated the same results as GHG, PICE, RE influence on GDP for EU countries. The obtained results were statistical significance $-1 \%$ for all three parameters. Thus, the increasing by $1 \%$ of PICE leads to increasing of GDP by $6.4 \%$ (FMOLS) and $5.6 \%$ (DMOLS), the increasing by $1 \%$ of GHG lead to increasing of GDP by $0.39 \%$ (FMOLS) and $0.41 \%$ (DMOLS), the increasing by $1 \%$ of RE provoked the increasing of GDP by $38.18 \%$ (FMOLS) and $37.24 \%$ (DMOLS).

It should be noted, that increasing of RE by $1 \%$ lead to decreasing of GHG by $-5139.85 \%$. Therefore, increasing by $1 \%$ of PICE provoked the increasing of RE by $5.6 \%$ (FMOLS) and 7\% (DOLS). At the same time, increasing of RE by $1 \%$ provoked the increasing of PICE by $99.44 \%$ (FMOLS).

The obtained results proved the hypothesis of linking between green investment, GDP, GHG emissions and share of renewable energy in the total energy consumption for EU countries. In this case, the findings proved that green investment could provoke the increase of the share of renewable energy in the total energy consumption and decreasing of GHG emissions. At the same time, the spreading of RE leads to declining of GHG.

Besides, all indicators green investment (PICE), GHG emission and share of renewable energy in the total energy consumption had a statistically significant impact on GDP. Thus, the increasing of green investment (PICE) could provoke the growth of GDP by $6.4 \%$, the declining of GHG by $3.08 \%$ and the increasing of renewable energy in the total energy consumption by $5.6 \%$ (FMOLS). 
The traditional investment market in the countries' potential candidate to EU membership should be "greening" (Figure 3).

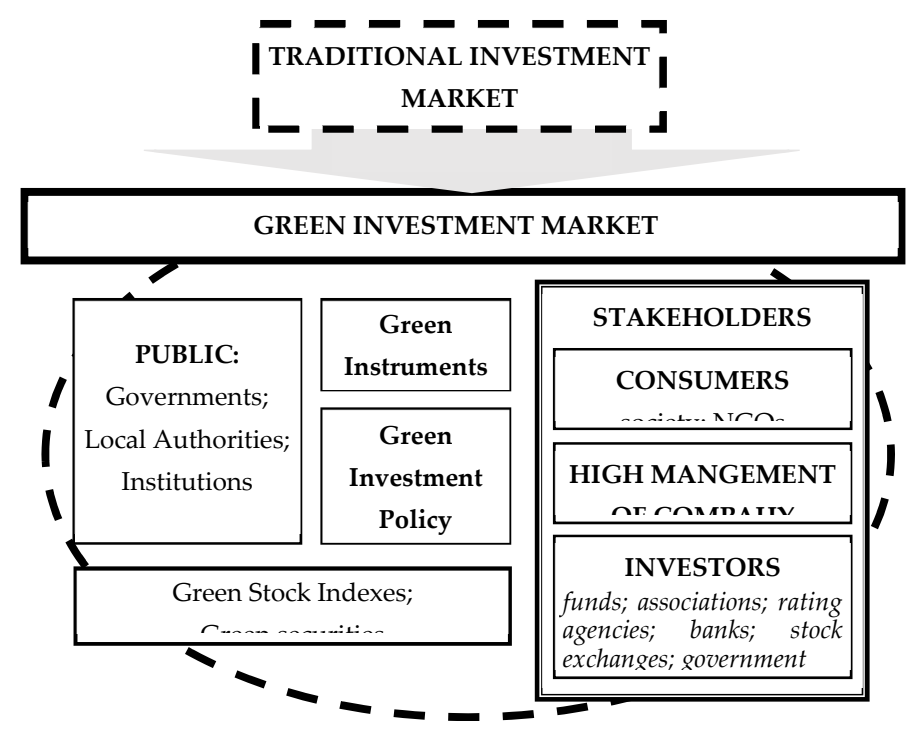

Figure 3. The framework concept of transformation from traditional to green investment market.

Source: developed by the authors on the basis [108-112,114,115].

The same analysis should be done for the countries' potential candidate to EU membership with the purpose to allocate the mechanism to minimize the negative imbalances in the EU on the way on achieving SDGs 2030. In this case, for further investigation, it is necessary to analyse the EU incentive mechanism to stimulate the attractiveness of green investment as a part of the direct foreign investment.

\section{Conclusions}

This empirical study has been operating data on the EU member states and the econometric modelling proves that green investments have a positive economic effect. The findings show that green investment could provoke the growth of GDP per capita by $6.4 \%$, reduction of GHG emissions by $3.08 \%$ and the increase of renewable energy in the total final energy consumption by $5.6 \%$. These findings proving there is cointegration between GDP and green investments are similar to the results presented in [32-45].

As the energy utility industries are the power generators of GDP and the causes of environmental damages in countries at the same time, their activities should be transformed according to the SDGs goals.

Such transformations so that to fit the SDGs require more of green investments for implementing more energy-efficient projects (oriented on renewable energy, clean technologies etc.). Together they would allow reducing GHG emissions.

The results of our analysis of the EU countries' experience in attracting green investments for renewable energy projects prove that openness and transparency of non-financial reporting are the main factors influencing investors' decisions.

Besides, regular publishing of non-financial reports leads to decreasing of greenwashing and strengthening of positive green brands. And this, in turn, would lead to increasing investing's attractiveness of companies for green investors.

As the EU experience shows, such reports should be published by companies on a regular basis and this norm should become obligatory on the government level. Moreover, potential candidates for the EU membership should analyse and implement incentive instruments so that to follow the principles of openness and transparency in their companies' non-financial reporting basing on the provided framework of transformation from traditional to green investment market. 
Author Contributions: S.L. and T.P., conceptualized this manuscript; T.P. prepared the database, methodology, software validation and wrote this manuscript, consolidated the literature reviewer; S.L., Y.B., D.Š., T.P. and G.M. reviewed the manuscript and assisted in writing and finalizing the manuscript.

Funding: This research was funded by the grant from the Ministry of Education and Science of Ukraine (№ g/r 0117U002251 and 0117U003932).

Conflicts of Interest: The authors declare no conflict of interest.

\section{References}

1. Raszkowski, A.; Bartniczak, B. Towards Sustainable Regional Development: Economy, Society, Environment, Good Governance Based on the Example of Polish Regions. Transform. Bus. Econ. 2018, 17, 225-245.

2. Dalevska, N.; Khobta, V.; Kwilinski, A.; Kravchenko, S. A model for estimating social and economic indicators of sustainable development. Entrep. Sustain. Issues 2019, 6, 1839-1860. [CrossRef]

3. Dabyltayeva, N.; Rakhymzhan, G. The green economy development path: Overview of economic policy priorities. J. Secur. Sustain. Issues 2019, 8, 643-651. [CrossRef]

4. Brożyna, J.; Mentel, G.; Szetela, B. Renewable energy and economic development in the European Union. Acta Polytech. Hung. 2017, 14, 11-34.

5. Matuszewska-Janica, A.; Żebrowska-Suchodolska, D.; Mentel, G. Evaluation of Short-Term Relationships between Selected Investment Funds and the Capital Market in Poland. Acta Polytech. Hung. 2019, 16, $25-41$.

6. Al-mulali, U.; Fereidouni, H.G.; Lee, J.Y.; Sab, C.N.B.C. Examining the bi-directional long run relationship between renewable energy consumption and GDP growth. Renew. Sustain. Energy Rev. 2013, 22, $209-222$. [CrossRef]

7. Ocal, O.; Aslan, A. Renewable energy consumption-economic growth nexus in Turkey. Renew. Sustain. Energy Rev. 2013, 28, 494-499. [CrossRef]

8. Sadorsky, P. Renewable energy consumption, $\mathrm{CO}_{2}$ emissions and oil prices in the $\mathrm{G} 7$ countries. Energy Econ. 2009, 31, 456-462. [CrossRef]

9. Chang, M.-C.; Shieh, H.-S. The Relations between Energy Efficiency and GDP in the Baltic Sea Region and Non-Baltic Sea Region. Transform. Bus. Econ. 2017, 16, 235-247.

10. Sachs, J.; Schmidt-Traub, G.; Kroll, C.; Lafortune, G.; Fuller, G. SDG Index and Dashboards Report 2018; Bertelsmann Stiftung and Sustainable Development Solutions Network (SDSN): New York, NY, USA, 2018.

11. European Environment Agency. Greenhouse Gas Emissions by Source Sector. 2019. Available online: https://ec.europa.eu/eurostat/data/database (accessed on 2 January 2019).

12. World Data Bank. World Development Indicators. 2019. Available online: https://databank.worldbank.org/ data/reports.aspx?source=2\&series=NY.GDP.PCAP.CD\&country=\# (accessed on 2 January 2019).

13. Chygryn, O.Y.; Krasniak, V.S. Theoretical and applied aspects of the development of environmental investment in Ukraine. Mark. Manag. Innov. 2015, 3, 226-234.

14. Štreimikienè, D.; Mikalauskienè, A.; Mikalauskas, I. Comparative Assessment of Sustainable Energy Development in the Czech Republic, Lithuania and Slovakia. J. Compet. 2016, 8, 31-41. [CrossRef]

15. Androniceanu, A.; Popescu, C.R. An inclusive model for an effective development of the renewable energies public sector. Adm. Public Manag. Rev. 2017, 81-96.

16. Anwar, S.; Nguyen, L.P. Foreign direct investment and economic growth in Vietnam. Asia Pac. Bus. Rev. 2010, 16, 183-202. [CrossRef]

17. Štreimikienè, D.; Strielkowski, W.; Bilan, Y.; Mikalauskas, I. Energy dependency and sustainable regional development in the Baltic states: A review. Geogr. Pannonica 2016, 20, 79-87. [CrossRef]

18. Djalilov, K.; Lyeonov, S.; Buriak, A. Comparative studies of risk, concentration and efficiency in transition economies. Risk Gov. Control Financ. Mark. Inst. 2015, 5, 178-187. [CrossRef]

19. Ibragimov, Z.; Lyeonov, S.; Pimonenko, T. Green investing for SDGS: EU experience for developing countries. Econ. Soc. Dev. Book Proc. 2019, 14, 867-876.

20. Chygryn, O.; Pimonenko, T.; Luylyov, O.; Goncharova, A. Green Bonds like the Incentive Instrument for Cleaner Production at the Government and Corporate Levels: Experience from EU to Ukraine. J. Environ. Manag. Tour. 2019, 9, 1443-1456. [CrossRef]

21. Kendiukhov, I.; Tvaronavičienė, M. Managing innovations in sustainable economic growth. Mark. Manag. Innov. 2017, 33-42. [CrossRef] 
22. Chygryn, $\mathrm{O}$. The mechanism of the resource-saving activity at joint stock companies: The theory and implementation features. Int. J. Ecol. Dev. 2016, 31, 42-59.

23. Li, J.; Sun, X.; Li, G. Relationships Among Green Brand, Brand Equity and Firm Performance: Empirical Evidence from China. Transform. Bus. Econ. 2018, 17, 221-236.

24. Martinez-Oviedo, R.; Medda, F. Real Natural Assets: The Real Green Investment Alternative. J. Altern. Investig. 2018, 21, 53-69.

25. Rajnoha, R.; Lesníková, P. Strategic Performance Management System and Corporate Sustainability Concept-Specific Parametres in Slovak Enterprises. J. Compet. 2016, 8, 107-154. [CrossRef]

26. Štreimikienè, D. Impact of environmental taxes on sustainable energy development in Baltic States, Czech Republic and Slovakia. Econ. Manag. 2015, 18, 4-23. [CrossRef]

27. Tvaronavičienè, A. The Possibilities to Use Public Procurement as One of the Instruments of Implementation of Sustainable Development Concept in Republic of Lithuania. Bus. Theory Pract. 2012, 13, $197-207$. [CrossRef]

28. Vakulenko, I.; Myroshnychenko, I. Approaches to the organization of the energy efficient activity at the regional level in the context of limited budget resources during the transformation of energy market paradigm. Environ. Clim. Technol. 2015, 15, 59-76. [CrossRef]

29. Vasylyeva, T.A.; Pryymenko, S.A. Environmental economic assessment of energy resources in the context of ukraine's energy security. Actual Probl. Econ. 2014, 160, 252-260.

30. Yildiz, T. Environmental Reporting of Industrial and Supply Chain Business Processes within the Context of Sustainable Development. Bus. Theory Pract. 2011, 12, 5-14. [CrossRef]

31. Zaim, O. Measuring environmental performance of state manufacturing through changes in pollution intensities: A DEA framework. Ecol. Econ. 2004, 48, 37-47. [CrossRef]

32. Atari, S.; Bakkar, Y.; Olaniyi, E.O.; Prause, G. Real options analysis of abatement investments for sulphur emission control compliance. Entrep. Sustain. Issues 2019, 6, 1062-1087. [CrossRef]

33. Bilan, Y.; Streimikiene, D.; Vasylieva, T.; Lyulyov, O.; Pimonenko, T.; Pavlyk, A. Linking between renewable energy, $\mathrm{CO}_{2}$ emissions, and economic growth: Challenges for candidates and potential candidates for the EU membership. Sustainability 2019, 11, 1528. [CrossRef]

34. Cherchyk, L.; Shershun, M.; Khumarova, N.; Mykytyn, T.; Cherchyk, A. Assessment of forest enterprises' performance: Integrating economic security and ecological impact. Entrep. Sustain. Issues 2019, 6, 1784-1797. [CrossRef]

35. Dabija, D.C.; Bejan, B.M.; Dinu, V. How sustainability oriented is generation z in retail? A literature review. Transform. Bus. Econ. 2019, 18, 140-155.

36. Bilan, Y.; Gavurova, B.; Stanisław, G.; Tkacova, A. The Composite Coincident Indicator (CCI) for Business Cycles. Acta Polytech. Hung. 2017, 14, 71-90.

37. Eyraud, L.; Clements, B.; Wane, A. Green investment: Trends and determinants. Energy Policy 2013, 60, 852-865. [CrossRef]

38. Kubicová, J. Testing greenhouse gasses in Slovakia for environmental Kuznets curve and pollution haven hypothesis. J. Int. Stud. 2015, 7, 161-177. [CrossRef] [PubMed]

39. Lapinskienė, G.; Peleckis, K.; Nedelko, Z. Testing environmental Kuznets curve hypothesis: The role of enterprise's sustainability and other factors on GHG in European countries. J. Bus. Econ. Manag. 2017, 18, 54-67. [CrossRef]

40. Lyeonov, S.; Stoyanets, N.; Vysochyna, A.; Bilan, Y. The impact of environmental determinants of sustainable agriculture on country food security. Int. J. Environ. Technol. Manag. 2018, 21, 289-305. [CrossRef]

41. Martin, P.R.; Moser, D.V. Managers' green investment disclosures and investors' reaction. J. Account. Econ. 2016, 61, 239-254. [CrossRef]

42. Mentel, G.; Vasilyeva, T.; Pryymenko, S.; Samusevych, Y. Regional differentiation of electricity prices: Social-equitable approach. Int. J. Environ. Technol. Manag. 2018, 21, 354. [CrossRef]

43. Vysochyna, A.V.; Samusevych, I.V.; Tykhenko, V.S. The effect of tax tools in environmental management on region's financial potential. Actual Probl. Econ. 2015, 171, 263-269.

44. Yazdani-Chamzini, A.; Fouladgar, M.M.; Zavadskas, E.K.; Moini, S.H.H. Selecting the optimal renewable energy using multi criteria decision making. J. Bus. Econ. Manag. 2013, 4, 957-978. [CrossRef] 
45. Balitskiy, S.; Bilan, Y.; Strielkowski, W.; Štreimikienè, D. Energy efficiency and natural gas consumption in the context of economic development in the European Union. Renew. Sustain. Energy Rev. 2016, 55, 156-168. [CrossRef]

46. Baran, B. Support for renewable energy in Germany as an example of effective public policy. Oeconomia Copernic. 2015, 6, 143-158. [CrossRef]

47. Cebula, J.; Pimonenko, T. Comparison financing conditions of the development biogas sector in poland and ukraine. Int. J. Ecol. Dev. 2015, 30, 20-30.

48. Chygryn, O.; Petrushenko, Y.; Vysochyna, A.; Vorontsova, A. Assessment of Fiscal Decentralization Influence on Social and Economic Development. Montenegrin J. Econ. 2018, 14, 069-084. [CrossRef]

49. Eddelani, O.; El Idrissi, N.E.; Monni, S. Territorialized forms of production in Morocco: Provisional assessment for an own model in gestation. Insights Reg. Dev. 2019, 1, 6-18. [CrossRef]

50. Ginevicius, R.; Gedvilaite, D.; Stasiukynas, A. Impact of economic development on the ecology in the regions of Lithuania. Econ. Manag. 2018, 21, 21-37. [CrossRef]

51. Hagspiel, V.; Dalby, P.A.O.; Gillerhaugen, G.R.; Leth-Olsen, T.; Thijssen, J.J.J. Green investment under policy uncertainty and Bayesian learning. Energy 2018, 161, 1262-1281. [CrossRef]

52. Lyulyov, O.; Chortok, Y.; Pimonenko, T.; Borovik, O. Ecological and economic evaluation of transport system functioning according to the territory sustainable development. Int. J. Ecol. Dev. 2015, 30, 1-10.

53. Pimonenko, T.; Chayen, S.V.; Cebula, J.; Chygryn, O. Biogas as an alternative energy source in Ukraine and Israel: Current issues and benefits. Int. J. Environ. Technol. Manag. 2018, 21, 421. [CrossRef]

54. Yevdokimov, Y.; Chygryn, O.; Pimonenko, T.; Lyulyov, O. Biogas as an alternative energy resource for ukrainian companies: EU experience. Innov. Mark. 2018, 14, 7-15. [CrossRef]

55. Mielke, J.; Steudle, G.A. Green Investment and Coordination Failure: An Investors' Perspective. Ecol. Econ. 2018, 150, 88-95. [CrossRef]

56. Pimonenko, T.; Prokopenko, O.; Dado, J. Net zero house: EU experience in Ukrainian conditions. Int. J. Ecol. Econ. Stat. 2017, 38, 46-57.

57. Prokopenko, O.; Cebula, J.; Chayen, S.; Pimonenko, T. Wind energy in Israel, Poland and Ukraine: Features and opportunities. Int. J. Ecol. Dev. 2017, 32, 98-107.

58. Simionescu, M.; Albu, L.L.; Raileanu Szeles, M.; Bilan, Y. The impact of biofuels utilisation in transport on the sustainable development in the European Union. Technol. Econ. Dev. Econ. 2017, 23, 667-686. [CrossRef]

59. Šincāns, E.; Ignatjeva, S.; Tvaronavičienè, M. Issues of Latvian Energy Supply Security: Evaluation of Criminal Offences in Latvia's Electricity Market. Econ. Sociol. 2016, 9, 322-335. [CrossRef]

60. Smaliukienè, R.; Monni, S. A step-by-step approach to social marketing in energy transition. Insights Reg. Dev. 2019, 1, 19-32. [CrossRef]

61. Suska-Szczerbicka, M. Wind energy financing tools. Econ. Sociol. 2010, 3, 141-160. [CrossRef]

62. Vasylyeva, T.A.; Leonov, S.V.; Lunyakov, O. Countercyclical capital buffer as a macroprudential tool for regulation of the financial sector. Actual Probl. Econ. 2014, 8, 278-283.

63. Zakharkina, L.; Myroshnychenko, I.; Smolennikov, D.; Pokhylko, S. Efficiency of Innovation Activity Funding as the Driver of the State's National Economic Security. Montenegrin J. Econ. 2018, 14, 159-173. [CrossRef]

64. Ptak, M. Directions of changes in the functioning of economic instruments for environmental policy in Poland. Equilib. Q. J. Econ. Econ. Policy 2015, 5, 129-140. [CrossRef]

65. Sjaifuddin, S. Environmental management prospects of industrial area: A case study on MCIE, Indonesia. Bus. Theory Pract. 2018, 19, 208-216. [CrossRef]

66. Štreimikienè, D.; Mikalauskienè, A. Green growth and use of EU structural funds in Baltic states, Czech Republic and Slovakia. Econ. Manag. 2016, 19, 55-72. [CrossRef]

67. Szyja, P. The role of the state in creating green economy. Oeconomia Copernic. 2016, 7, 207-222. [CrossRef]

68. Dkhili, H. Environmental performance and institutions quality: Evidence from developed and developing countries. Mark. Manag. Innov. 2018, 3, 333-344. [CrossRef]

69. Stjepanović, S.; Tomić, D.; Škare, M. A new approach to measuring green GDP: a cross-country analysis. Entrep. Sustain. Issues 2017, 4, 574-590. [CrossRef]

70. Vasilyeva, T.; Lyeonov, S.; Adamičková, I.; Bagmet, K. Institutional quality of social sector: The essence and measurements. Econ. Sociol. 2018, 11, 248-262. [CrossRef]

71. Vasylieva, T.A.; Kasyanenko, V.O. Integral assessment of innovation potential of Ukraine's national economy: A scientific methodical approach and practical calculations. Actual Probl. Econ. 2013, 144, 50-59. 
72. Xiong, Z.; Ye, J.; Wang, P. Does the institutional environment affect the failed technological innovation in firms? Evidence from listed companies in china's pharmaceutical manufacturing industry. Transform. Bus. Econ. 2019, 18, 60-80.

73. Abaas, M.S.M.; Chygryn, O.; Kubatko, O.; Pimonenko, T. Social and economic drivers of national economic development: The case of OPEC countries. Probl. Perspect. Manag. 2018, 16, 155-168. [CrossRef]

74. Abrhám, J.; Britchenko, I.; Jankovic, M.; Garškaitè-Milvydienè, K. Energy Security Issues in Contemporary Europe. J. Secur. Sustain. Issues 2018, 7, 387-398. [CrossRef]

75. Bajdor, P. Comparison between sustainable development concept and Green Logistics: The literature review. Pol. J. Manag. Stud. 2012, 5, 225-233.

76. Ivanova, E.; Kordos, M. Competitiveness and innovation performance of regions in Slovak Republic. Mark. Manag. Innov. 2017, 145-158. [CrossRef]

77. Lapinskienè, G.; Peleckis, K.; Slavinskaitè, N. Energy consumption, economic growth and greenhouse gas emissions in the European Union countries. J. Bus. Econ. Manag. 2017, 18, 1082-1097. [CrossRef]

78. Lavrinenko, O.; Ignatjeva, S.; Ohotina, A.; Rybalkin, O.; Lazdans, D. The Role of Green Economy in Sustainable Development (Case Study: The EU States). Entrep. Sustain. Issues 2019, 6, 1113-1126. [CrossRef]

79. Lyeonov, S.V.; Vasylieva, T.A.; Lyulyov, O.V. Macroeconomic stability evaluation in countries of lower-middle income economies. Nauk. Visnyk Natsionalnoho Hirnychoho Universytetu 2018, 138-146. [CrossRef]

80. Maftei, D. A new approach for energy security: The efficient management of funds for investment in infrastructure for green energy. Pol. J. Manag. Stud. 2012, 5, 242-249.

81. Masood, O.; Tvaronavičienè, M.; Javaria, K. Impact of oil prices on stock return: Evidence from G7 countries. Insights Reg. Dev. 2019, 1, 129-137. [CrossRef]

82. Okuneviciute Neverauskiene, L.; Rakauskiene, O. Identification of employment increasing possibilities in the context of the EU socioeconomic environment evaluation: The case of Lithuania. Econ. Sociol. 2018, 11, 51-68. [CrossRef]

83. Vasilyeva, T.A.; Leonov, S.V.; Lunyakov, O.V. Analysis of internal and external imbalances in the financial sector of Ukraine's economy. Actual Probl. Econ. 2013, 150, 176-184.

84. Gupta, R. Socioeconomic challenges and its inhabitable global illuminations. Bus. Ethics Leadersh. 2017, 2, 81-85. [CrossRef]

85. Kasperowicz, R.; Pinczyński, M.; Khabdullin, A. Modeling the power of renewable energy sources in the context of classical electricity system transformation. J. Int. Stud. 2017, 10, 264-272. [CrossRef]

86. Lu, J.; Ren, L.; Lin, W.; He, Y.; Streimikis, J. Policies to Promote Corporate Social Responsibility (CSR) and Assessment of CSR Impacts. Econ. Manag. 2019, 22, 82-98. [CrossRef]

87. Kharlamova, G.; Vertelieva, O. The international competitiveness of countries: Economic-mathematical approach. Econ. Sociol. 2013, 6, 39-52. [CrossRef]

88. Kharlamova, G.; Chernyak, O.; Nate, S. Renewable energy and security for Ukraine: Challenge or smart way? J. Int. Stud. 2018, 9, 88-115. [CrossRef]

89. Greco, F. Resilience: Transform adverse events into an opportunity for growth and economic sustainability through the adjustment of emotions. Bus. Ethics Leadersh. 2018, 2, 44-52. [CrossRef]

90. Leonov, S.V.; Vasylieva, T.A.; Tsyganyuk, D.L. Formalization of functional limitations in functioning of co-investment funds basing on comparative analysis of financial markets within FM CEEC. Actual Probl. Econ. 2012, 134, 75-85.

91. Leonov, S. Potential of Institutional Investors and Stock Market Development as an Alternative to Households Savings Allocations in Banks. Економічний часопис-XXI 2014, 11-12, 65-68.

92. Panayotou, T. Empirical Tests and Policy Analysis of Environmental Degradation at Different Stages of Economic Development; No. 992927783402676; International Labour Organization: Geneva, Switzerland, 1993.

93. Arribas, I.; Espinós-Vañó, M.D.; García, F.; Tamosiuniene, R. Negative screening and sustainable portfolio diversification. Entrep. Sustain. Issues 2019, 6, 1566-1586. [CrossRef]

94. Vasile, E.; Balan, M.; Balan, G.-S.; Grabara, I. Measures to reduce transportation greenhouse gas emissions in Romania. Pol. J. Manag. Stud. 2012, 6, 215-223.

95. Zajaczkowska, M. Prospects for the development of prosumer energy in Poland. Oeconomia Copernic. 2016, 7, 439-449. [CrossRef]

96. Kisiała, W.; Suszyńska, K. Economic growth and disparities: An empirical analysis for the Central and Eastern European countries. Equilib. Q. J. Econ. Econ. Policy 2017, 12, 613-631. [CrossRef] 
97. Malkina, M. Contribution of various income sources to interregional inequality of the per capita income in the Russian Federation. Equilib. Q. J. Econ. Econ. Policy 2017, 12, 399-416. [CrossRef]

98. Singh, S.N. Regional Disparity and Sustainable Development in NorthEastern States of India: A Policy Perspective. Socioecon. Chall. 2018, 2, 41-48. [CrossRef]

99. Yevdokimov, Y.; Melnyk, L.; Lyulyov, O.; Panchenko, O.; Kubatko, V. Economic freedom and democracy: Determinant factors in increasing macroeconomic stability. Probl. Perspect. Manag. 2018, 16, 279-290. [CrossRef]

100. Alfaro, L.; Chanda, A.; Kalemli-Ozcan, S.; Sayek, S. FDI and economic growth: The role of local financial markets. J. Int. Econ. 2004, 64, 89-112. [CrossRef]

101. Bhandari, M.P. Impact of Tourism of Off Road Driving on Vegetation Biomass, a Case Study of Masai Mara National Reserve, Narok, Kenya. Socioecon. Chall. 2018, 3, 6-25. [CrossRef]

102. Bhowmik, D. Financial Crises and Nexus Between Economic Growth and Foreign Direct Investment. Financ. Mark. Inst. Risks 2018, 2, 58-74. [CrossRef]

103. Fogarassy, C.; Neubauer, É.; Mansur, H.; Tangl, A.; Oláh, J.; Popp, J. The main transition management issues and the effects of environmental accounting on financial performance-with focus on cement industry. Adm. Manag. Public 2018, 31, 52-66. [CrossRef]

104. Lin, B.; Benjamin, I.N. Causal relationships between energy consumption, foreign direct investment and economic growth for MINT: Evidence from panel dynamic ordinary least square models. J. Clean. Prod. 2018, 197, 708-720. [CrossRef]

105. Lyulyov, O.; Chygryn, O.; Pimonenko, T. National brand as a marketing determinant of macroeconomic stability. Mark. Manag. Innov. 2018, 142-152. [CrossRef]

106. Mačaitytè, I.; Virbašiūtè, G. Volkswagen Emission Scandal and Corporate Social Responsibility-A Case Study. Bus. Ethics Leadersh. 2018, 2, 6-13. [CrossRef]

107. Mashokhida, A.; Khabibovich, A.A.; Pálka, P.; Shakhlo, R. The competitiveness and sustainable economic development of tajikistan regions. J. Compet. 2018, 10, 73-88. [CrossRef]

108. Bilan, Y.; Vasylieva, T.; Lyeonov, S.; Tiutiunyk, I. Shadow economy and its impact on demand at the investment market of the country. Entrep. Bus. Econ. Rev. 2019, 7, 27-43. [CrossRef]

109. Sokolenko, L.F.; Tiutiunyk, I.V.; Leus, D.V. Ecological and economic security assessment in the system of regional environmental management: A case study of ukraine. Int. J. Ecol. Dev. 2017, 32, 27-35.

110. Vasylieva, T.; Lyulyov, O.; Bilan, Y.; Streimikiene, D. Sustainable economic development and greenhouse gas emissions: The dynamic impact of renewable energy consumption, GDP, and corruption. Energies 2019, 12, 3289. [CrossRef]

111. Bilan, Y.; Vasilyeva, T.; Lyulyov, O.; Pimonenko, T. EU vector of Ukraine development: Linking between macroeconomic stability and social progress. Int. J. Bus. Soc. 2019, 20, 433-450.

112. Ch, A.R.; Semenoh, A.Y. Non-bank financial institutions activity in the context of economic growth: Cross-country comparisons. Financ. Mark. Inst. Risks 2017, 1, 39-49.

113. Private Investments, Jobs and Gross Value Added Related to Circular Economy Sectors. Eurostat. 2019. Available online: https://ec.europa.eu/eurostat/databrowser/view/cei_cie010/default/table?lang=en (accessed on 2 January 2019).

114. Vasilyeva, T.; Sysoyeva, L.; Vysochyna, A. Formalization of factors that are affecting stability of ukraine banking system. Risk Gov. Control Financ. Mark. Inst. 2016, 6, 7-11. [CrossRef]

115. Bilan, Y.; Lyeonov, S.; Lyulyov, O.; Pimonenko, T. Brand management and macroeconomic stability of the country. [Zarządzanie marką i stabilność makroekonomiczna kraju]. Pol. J. Manag. Stud. 2019, 19, 61-74. [CrossRef]

(C) 2019 by the authors. Licensee MDPI, Basel, Switzerland. This article is an open access article distributed under the terms and conditions of the Creative Commons Attribution (CC BY) license (http://creativecommons.org/licenses/by/4.0/). 